\title{
Analisis Koleksem Khas dan Potensinya untuk Kajian Kemiripan Makna Konstruksional dalam Bahasa Indonesia
}

\author{
1, 2 Gede Primahadi Wijaya Rajeg \& ${ }^{1}$ I Made Rajeg \\ ${ }^{1}$ Universitas Udayana, Indonesia \& ${ }^{2}$ Monash University, Australia \\ primahadiwijaya@gmail.com \& made_rajeg@unud.ac.id
}

\begin{abstract}
ABSTRAK
Makalah ini mengenalkan Analisis Koleksem Khas (Distinctive Collexeme Analysis) dan mengulas potensinya terhadap salah satu isu linguistik dalam Bahasa Indonesia (BI), yaitu perbedaan semantis pasangan verba kausatif deajektiva sebagai pencontohan dua konstruksi kausatif morfologis (yaitu $[$ per- $+\mathrm{AJ}]$ dan $[\mathrm{AJ}+-k a n]$ ), yang, menurut salah satu buku tatabahasa BI, perbedaan maknanya dianggap tidak begitu disadari oleh kebanyakan penutur BI. Dengan menggunakan pasangan kata memperbesar dan membesarkan sebagai contoh awal, ditemukan adanya perbedaan substansial berdasarkan distribusi dan tipe semantis koleksem R1 khas pada masing-masing verba. Lebih lanjut, koleksem khas kedua verba tersebut mencerminkan ciri semantis dominan yang dilandasi dengan dua metafora konseptual berbeda: (i) PENTING ADALAH BESAR untuk membesarkan, dan (ii) metafora ikutan dari KUANTITAS ADALAH UKURAN, yaitu LEBIH (BANYAK) ADALAH BESAR, untuk memperbesar.
\end{abstract}

Kata kunci: Linguistik Korpus Kuantitatif; Analisis Koleksem Khas; Korpus Bahasa Indonesia Leipzig; konstruksi kausatif morfologis Bahasa Indonesia; kemiripan makna; metafora konseptual

\begin{abstract}
This contribution introduces Distinctive Collexeme Analysis (DCA) and explores its potential to address a theoretical issue in Indonesian linguistics, namely semantic dissimilarity between a pair of deadjectival causative verbs of the same root realising two causative morphological constructions, which, according to one of the Indonesian grammar textbooks, are assumed to be semantically indistinguishable by many Indonesian speakers; the constructions are [per- + ADJ] and [ADJ + -kan]. Using the pair of active-voiced verbs with the root besar 'big' (i.e. memperbesar and membesarkan) as a preliminary example, we demonstrate that there are substantial distributional and semantic differences concerning the distinctive R1 collexemes of these verbs. We argue that the predominant semantics of the verbs based on their distinctive collexemes reflect two different metaphorical conceptualisations: (i) IMPORTANCE IS BIG for membesarkan, and (ii) the entailment of QUANTITY IS SIZE metaphor, namely MORE IS BIG, for memperbesar.
\end{abstract}

Keywords: Quantitative Corpus Linguistics; Distinctive Collexeme Analysis; Indonesian Leipzig Corpora; Indonesian morphological causative constructions; nearsynonymy; conceptual metaphors 


\section{PENGANTAR ${ }^{1}$}

Perkembangan linguistik terkini mencakup pemanfaatan bank data elektronik kebahasaan (atau korpus) dan penerapan beragam metode analisis kuantitatif guna mengkaji aspek-aspek kebahasaan (Janda, 2017). Keberadaan korpus sebagai sumber data pemakaian bahasa, beserta informasi kuantitatif yang ditawarkan, memungkinkan peneliti untuk meninjau kembali asumsi-asumsi teoretis dari penelitian sebelumnya melalui pendekatan berbeda. Makalah ini mencoba menunjukkan bagaimana suatu klaim teoretis dapat ditinjau dan diuji melalui data korpus dan metode linguistik korpus kuantitatif. Secara khusus, makalah ini membahas klaim terkait dua konstruksi kausatif morfologis dalam Bahasa Indonesia (BI), yaitu [per- + AJ(EKTIVA)] dan [AJ(EKTIVA) + -kan]; kajian ini sekaligus melanjutkan penelitian korpus sebelumnya perihal konstruksi [per- + AJ] (G. P. W. Rajeg \& Rajeg, 2017). Penulis akan menguji salah satu klaim yang diajukan oleh Sneddon et al. (2010, hlm. 103) terkait kemiripan semantis verba kausatif deajektiva dalam skema konstruksi morfologis per-dan -kan.

Secara teoretis, terdapat perbedaan kandungan semantis yang disampaikan oleh verba deajektiva yang dilandasi dengan konstruksi per- dan -kan. Verba kausatif dengan -kan dipandang menyampaikan makna bahwa 'objek langsungnya disebabkan memiliki ciri yang dirujuk oleh akar ajektivanya dan yang belum dimiliki sebelumnya', sedangkan verba kausatif dengan per- dianggap memiliki unsur komparatif dalam kandungan semantisnya, yaitu bahwa 'objek langsungnya disebabkan untuk memiliki peningkatan kadar ciri yang telah ada sebelumnya' (Sneddon et al., 2010, hlm. 103). Salah satu contohnya ialah pasangan kata membesarkan ('membuat sesuatu yang sebelumnya tidak besar menjadi besar') dan memperbesar ('membuat sesuatu yang sudah besar menjadi lebih besar'). Akan tetapi, Sneddon et al. (2010, hlm. 103) menambahkan bahwa kebanyakan penutur BI pada umumnya tidak mengenali perbedaan semantis yang dimiliki oleh kedua konstruksi tersebut terhadap verba turunannya, meskipun keragaman pemakaian di antara penutur bisa saja ditemukan:

"It is probable there is considerable variation in usage between different speakers, with many people making no distinction between the functions of the two affixes." (Sneddon et al., 2010, hlm. 103)

Sneddon et al. khususnya berasumsi bahwa kebanyakan penutur memahami verba dengan per- sebagai tindakan yang menyebabkan objek langsungnya memiliki ciri yang dirujuk oleh akar ajektivanya, terlepas dari apakah ciri tersebut sudah dimiliki sebelumnya ataupun belum. Selain klaim terkait ketidaksadaran penutur terhadap perbedaan makna dari kedua konstruksi tersebut, Sneddon et al (2010, hlm. 103) juga menambahkan bahwa terdapat pasangan verba kausatif per- dan -kan yang secara semantis tidak dapat saling menggantikan karena memiliki makna lazim yang berbeda. Salah satu contoh pasangan kata yang diberikan ialah memperpanjang dan memanjangkan. Dalam hal ini, memperpanjang dianggap hanya digunakan pada ranah temporal dan memanjangkan untuk ranah fisik.

Asumsi terkait pemahaman penutur atas kemiripan dan/atau perbedaan pasangan verba kausatif deajektiva dengan per- dan -kan bisa diuji, misalnya melalui experimen psikolinguistik. Namun, makalah ini mencoba merumuskan asumsi tersebut untuk

\footnotetext{
${ }^{1}$ Penelitian dan penulisan makalah ini didukung oleh skema dana penelitian doktoral dari Monash University, Australia yang diberikan kepada GPWR, yaitu Monash International Postgraduate Research Scholarships (MIPRS) dan Monash Graduate Scholarships (MGS).
} 
terlebih dahulu dapat diuji melalui data pemakaian dalam korpus. Asumsinya ialah sebagai berikut.

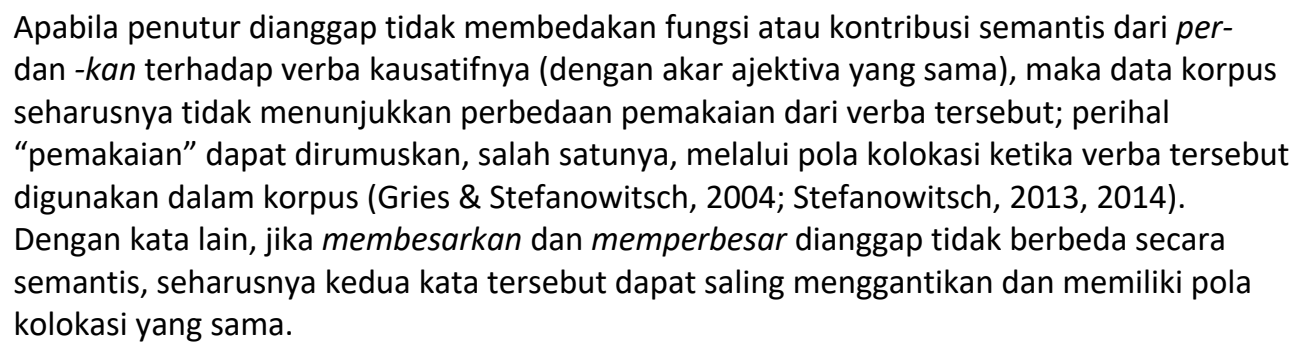

Rumusan asumsi di atas berpijak pada pendekatan semantik distribusional (lihat Lenci, 2008 untuk pengantar) yang menyatakan bahwa (i) makna suatu unsur linguistik (mis. kata) dapat dicirikan berdasarkan konteks pemakaiannya (mis. kolokasi) (Gries \& Stefanowitsch, 2004, hlm. 100), dan (ii) perbedaan makna antara dua atau lebih kata tercermin dalam perbedaan distribusi konteks kata tersebut. Sebagai contoh permulaan, asumsi tersebut akan diujikan pada pasangan kata membesarkan dan memperbesar menggunakan salah satu metode linguistik korpus kuantitatif, yaitu Analisis Koleksem Khas atau Distinctive Collexeme Analysis (DCA) (Gries, 2013; Gries \& Stefanowitsch, 2004) (§2.2).

Berdasarkan analisis korpus kuantitatif dengan DCA (\$3), penulis menunjukkan bukti awal adanya perbedaan semantis substansial di antara salah satu pasangan verba kausatif berkonstruksi [per- $+\mathrm{AJ}]$ dan $[\mathrm{AJ}+-k a n]$. Penulis juga berpendapat bahwa koleksem khas dari memperbesar dan membesarkan mencerminkan dua konseptualisasi metaforis berbeda yang melandasi makna dominan dari kedua verba tersebut. Temuan ini dipandang dapat mendukung salah satu asumsi dari Sneddon et al (2010, hlm. 103) bahwa terdapat pasangan verba yang tidak dapat saling menggantikan.

\section{DATA DAN METODE}

\subsection{Berkas Korpus dan Pencarian Koleksem}

Makalah ini menggunakan lima berkas korpus surat kabar daring (Tabel 1) yang menjadi bagian dari Korpus Leipzig Bahasa Indonesia (Biemann, Heyer, Quasthoff, \& Richter, 2007). Kelima korpus ini secara keseluruhan berjumlah 29,343,544 juta kata.

\section{Tabel 1 Berkas korpus Leipzig yang digunakan beserta ukurannya.}

\begin{tabular}{ll} 
Berkas korpus & Jumlah kata \\
\hline ind_news_2008_300K-sentences.txt & $5,875,376$ \\
ind_news_2009_300K-sentences.txt & $5,868,276$ \\
ind_news_2010_300K-sentences.txt & $5,874,158$ \\
ind_news_2011_300K-sentences.txt & $5,852,211$ \\
ind_news_2012_300K-sentences.txt & $5,873,523$
\end{tabular}

Pencarian koleksem dilakukan menggunakan piranti pemrograman R (R Core Team, 2018), khususnya melalui fungsi colloc_leipzig( ), yang terdapat dalam modul collogetr (G. P. W. Rajeg, 2018a). Koleksem untuk memperbesar dan membesarkan dibatasi pada lingkup satu kata di sebelah kanan kedua verba tersebut (atau disebut dengan koleksem R1). Pilihan ini dilandasi dengan dua asumsi. Pertama, satu kata yang 
tepat mengikuti verba transitif tersebut diasumsikan sebagai objek langsungnya. Kedua, objek langsung yang secara kuantitatif khas mengikuti verba tersebut dipandang sebagai salah satu konteks penting guna mencirikan perbedaan semantis kedua verba transitif tersebut (\$2.2); makalah ini akan menunjukkan bagaimana pencirian semantis berbasis koleksem tersebut dapat dibahas secara kualitatif $(\S 3)$.

\subsection{Analisis Koleksem Khas}

Analisis Koleksem Khas (DCA) merupakan salah satu ragam dari gugusan metode linguistik korpus kuantitatif yang disebut Analisis Kolostruksional (Collostructional Analysis $^{2}$, selanjutnya CA) (Stefanowitsch, 2013, 2014; Stefanowitsch \& Gries, 2003). DCA dikembangkan untuk mengkaji perbedaan dua konstruksi, yang mirip secara semantis/fungsional, berdasarkan unsur leksikal (disebut koleksem) yang memiliki keterkaitan khas secara statistik terhadap satu dari kedua konstruksi tersebut. Sebagai contoh, DCA dapat digunakan untuk membedakan konstruksi Datif Preposisional dengan Ditransitif; konstruksi Will + infinitive dengan be going to + infinitive; atau konstruksi Aktif dengan Pasif (Gries \& Stefanowitsch, 2004; lihat juga Stefanowitsch, 2013, hlm. 302-303, untuk rentangan terkini penerapan CA secara umum). Penerapan DCA pada data Bahasa Indonesia khususnya telah mencakup kajian interaksi antara metafora dan sinonim emosi (G. P. W. Rajeg, 2014, 2016, 2018b) dan konstruksi negasi dengan tak dan tidak (G. P. W. Rajeg, Denistia, \& Rajeg, 2018).

Makalah ini bertujuan melihat potensi DCA untuk menemukan perbedaan pemakaian sepasang verba pencontohan dua konstruksi kausatif morfologis pada BI, yaitu [per- + $\mathrm{AJ}]$ dan $[\mathrm{AJ}+-k a n]$, yang perbedaan maknanya tidak diperhatikan oleh kebanyakan penutur BI (periksa §1). Analisis statistik dalam DCA didasari dengan tabulasi kekerapan dua dimensi seperti pada Tabel 2, yang mencontohkan distribusi nomina jumlah sebagai koleksem R1 untuk memperbesar dan membesarkan dalam kelima berkas korpus pada Tabel 1 di atas.

Tabel 2 Tabulasi silang dua dimensional sebagai masukan $\mathrm{DCA}^{3}$

\begin{tabular}{llll} 
& memperbesar & membesarkan & Total \\
\hline jumlah & $\mathbf{9}(5.77)$ & $1(4.23)$ & 10 \\
$\neg$ jumlah & $408(411.23)$ & $305(301.77)$ & 713 \\
Total & 417 & 306 & 723
\end{tabular}

Nilai dalam kurung "(...)" merupakan kekerapan harapan (expected frequency) untuk tiap-tiap sel apabila diasumsikan bahwa suatu koleksem memiliki rasio distribusi yang setara untuk kedua konstruksi. Sedangkan nilai yang tidak dikurung ialah nilai pengamatan dalam korpus. Nilai harapan masing-masing sel diperoleh dengan mengalikan jumlah total kolom dan baris yang dibagi dengan nilai total tabel (yang ada di pojok kanan bawah). Misalnya, penghitungan nilai harapan untuk sel jumlah dan membesarkan ialah $(306 \cdot 10) / 723=4.23$.

\footnotetext{
2 Unsur collostruction pada Collostructional Analysis (CA) merupakan perpaduan antara kata collocation dan construction (Stefanowitsch \& Gries, 2003). CA ialah salah satu metode lazim dalam kajian yang dilandasi pendekatan konstruksional, seperti Tatabahasa Konstruksi (Construction Grammar) (Stefanowitsch, 2013).

3 Tanda “ $\neg ”$ pada baris “ $\neg$ jumlah” menyatakan kekerapan koleksem selain jumlah.
} 
CA mengukur nilai keterkaitan, yang diistilahkan dengan Kadar Kekhasan

(Distinctiveness), antara suatu koleksem dan salah satu dari kedua konstruksi

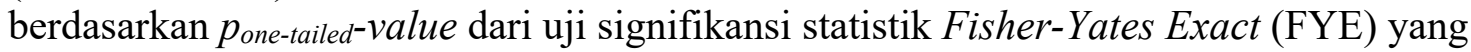
kemudian diubah menjadi nilai log negatif 10 (Gries, 2013). Sel yang diperhatikan dari masukan tabel seperti pada Tabel 2 ialah pertemuan antara baris dan kolom pertama, yaitu sel $a$ (ditebalkan pada Tabel 2). Perbandingan dilakukan terkait apakah nilai sel $a$ muncul lebih sering atau jarang dari yang diharapkan karena ini akan menentukan (i) parameter terkait uji FYE yang dilakukan, serta (ii) arah asosiasi (positif/khas atau negatif/tertolak) antara koleksem (baris) dan salah satu dari dua konstruksi yang dikaji (kolom). Berikut ini adalah kode untuk melakukan FYE melalui R. Data masukannya ialah empat sel (selain nilai Total) pada Tabel 2; mengingat sel $a$-nya lebih tinggi dari yang diharapkan, parameter alternative pada fungsi fisher.test() di bawah diberi masukan "greater".

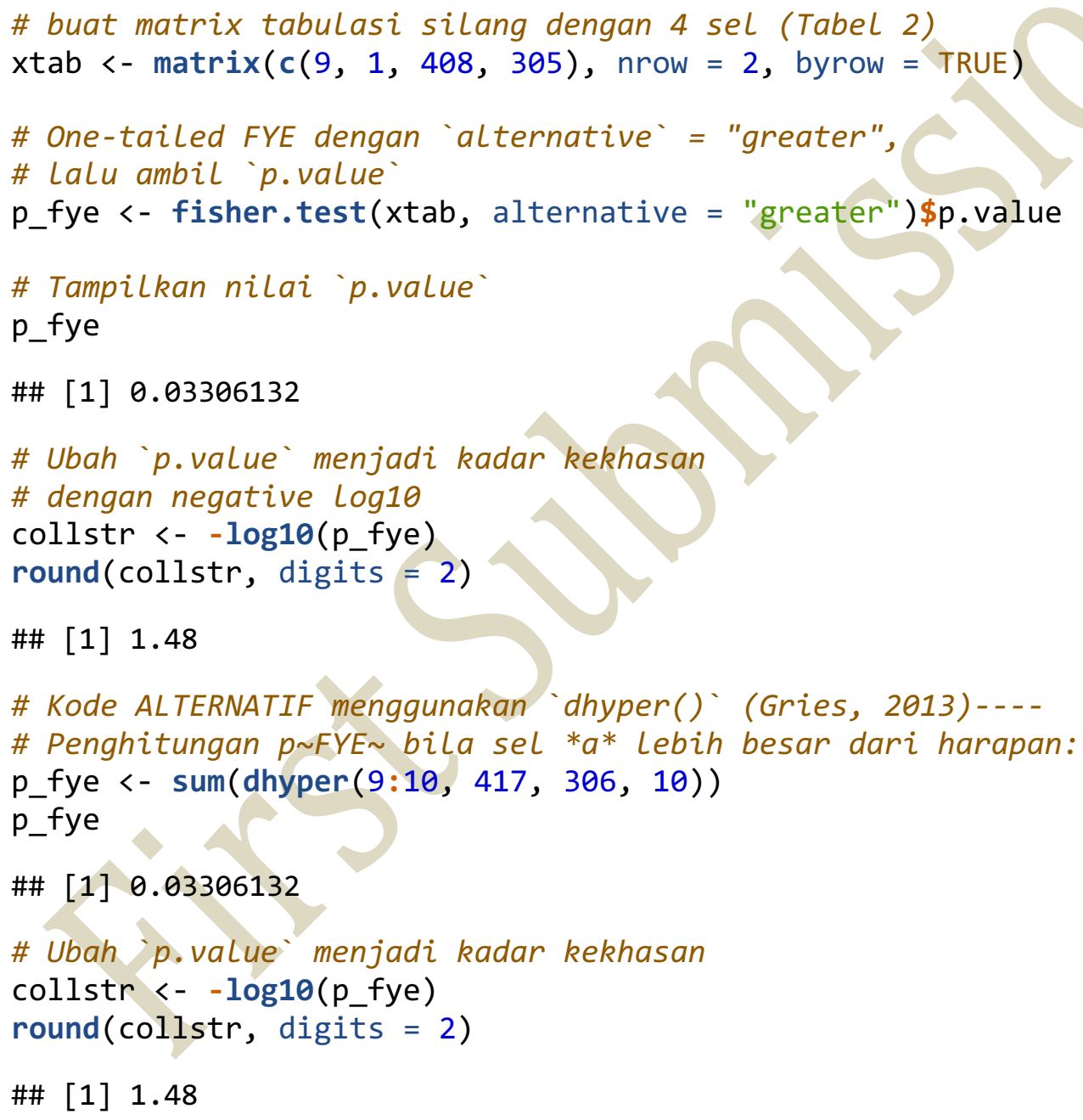

Tingkat signifikansi keterkaitan antara suatu koleksem dengan satu dari kedua konstruksi umumnya dibatasi pada $p_{\mathrm{FYE}}<0.05$, yang menghasilkan Kadar Kekhasan (collstr) $>1.30103$ jika diubah menjadi nilai log negative 10. Koleksem yang (secara signifikan) muncul lebih sering dari yang diharapkan dengan salah satu dari kedua konstruksi tersebut (dan yang otomatis membuat koleksem tersebut [secara signifikan] muncul lebih sedikit dari yang diharapkan dengan konstruksi yang lain) diistilahkan dengan koleksem khas (signifikan) untuk konstruksi tersebut. Untuk Tabel 2, nilai 
$p_{\text {FYE }}$ ialah 0.033 (lebih kecil dari 0.05) dan memiliki collstr $=1.48$. Luaran FYE tersebut, dan perbandingan kekerapan pengamatan dengan yang diharapkan, menunjukkan bahwa jumlah merupakan koleksem R1 khas signifikan untuk memperbesar tapi tidak untuk membesarkan.

Keterkaitan sebaliknya ditunjukkan oleh $P A N$ (salah satu partai politik di Indonesia) pada Tabel 3 berikut yang memiliki asosiasi positif dengan membesarkan $\left(\right.$ collstr $\left._{\text {membesarkan }}=1.6 ; p_{\mathrm{FYE}}=0.025\right)$ tapi tidak dengan memperbesar, yang muncul dengan $P A N$ lebih sedikit dari yang diharapkan.

Tabel 3 Tabulasi silang bila sel $a$ lebih kecil dari harapan

\begin{tabular}{llll} 
& memperbesar & membesarkan & Total \\
\hline$P A N$ & $\mathbf{1}(4.04)$ & $6(2.96)$ & 7 \\
$\neg P A N$ & $416(412.96)$ & $300(303.04)$ & 716 \\
Total & 417 & 306 & 723
\end{tabular}

Apabila nilai pengamatan pada sel $a$ lebih kecil dari yang diharapkan seperti pada Tabel 3, parameter alternative dalam uji statistik FYE di R diberi masukan "less".

Perhatikan nukilan kode $\mathrm{R}$ berikut.

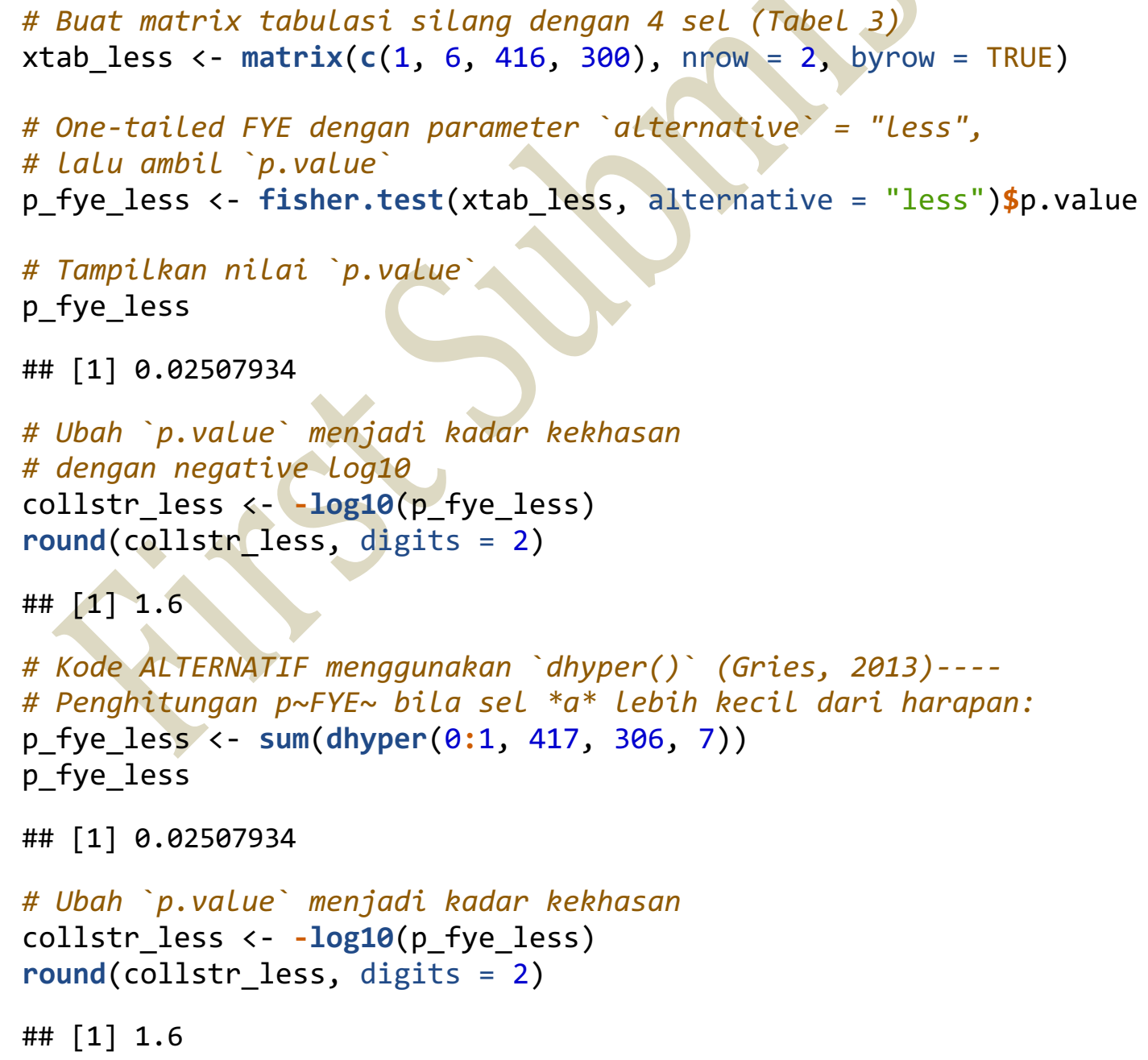


Penghitungan yang sama dapat dilakukan untuk semua koleksem R1 yang muncul paling tidak satu kali dengan memperbesar atau membesarkan. Kemudian, koleksem ini dapat diurutkan berdasarkan Kadar Kekhasan terhadap satu dari kedua verba tersebut. Daftar koleksem khas ini menjadi data pemakaian empiris guna menafsirkan pencirian dan perbedaan semantis kedua konstruksi tersebut (\$3). Data dan berkas $R$ Markdown Notebook, yang digunakan untuk menulis makalah ini dan berisikan kode pemrograman $\mathrm{R}$ untuk semua analisis kuantitatif, dapat diunduh melalui dua tautan berikut: https://github.com/gederajeg/analisis_koleksem_khas atau https://doi.org/10.26180/5bf4e49ea1582.

\section{HASIL DAN PEMBAHASAN}

Tabel 4 menampilkan koleksem R1 khas yang secara signifikan lebih sering muncul dengan membesarkan dibandingkan dengan memperbesar; nilai dalam kurung adalah kekerapan harapan.

\section{Tabel 4 Koleksem R1 khas signifikan untuk membesarkan dibandingkan dengan} memperbesar

\begin{tabular}{lllll} 
& koleksem & memperbesar & membesarkan & collstr \\
\hline 1 & partai & $0(41.53)$ & $72(30.47)$ & 29.25 \\
2 & hati & $0(19.03)$ & $33(13.97)$ & 12.78 \\
3 & anak & $0(10.38)$ & $18(7.62)$ & 6.85 \\
4 & pkb & $0(7.5)$ & $13(5.5)$ & 4.92 \\
5 & namanya & $0(5.77)$ & $10(4.23)$ & 3.77 \\
6 & nama & $0(4.61)$ & $8(3.39)$ & 3.01 \\
7 & anak-anak & $0(4.04)$ & $7(2.96)$ & 2.63 \\
8 & nu & $0(4.04)$ & $7(2.96)$ & 2.63 \\
9 & pan & $1(4.04)$ & $6(2.96)$ & 1.60 \\
10 & anak-anaknya & $0(2.31)$ & $4(1.69)$ & 1.50 \\
11 & ketiga & $0(2.31)$ & $4(1.69)$ & 1.50 \\
12 & organisasi & $0(2.31)$ & $4(1.69)$ & 1.50 \\
13 & pks & $0(2.31)$ & $4(1.69)$ & 1.50
\end{tabular}

Jika diamati dari segi distribusi ketigabelas koleksem khas signifikan pada Tabel 4, tampak jelas bahwa hanya $P A N$ yang juga muncul satu kali dengan memperbesar. Koleksem lainnya sama sekali tidak pernah muncul sebagai koleksem R1 dari memperbesar. Hal ini sedikitnya mengindikasikan perbedaan substantial mengenai pemakaian dan pilihan pola kolokasi di antara membesarkan dan memperbesar.

Secara semantis, tampak bahwa koleksem R1 khas untuk membesarkan didominasi oleh nomina yang merujuk pada konsep organisasi (seperti partai, organisasi, $N U$ ), khususnya partai politik ( $P K B, P A N, P K S)$.

(1) "Kami siap membesarkan Partai Demokrat di tahun 2014." (ind_news_2011_300K:116578)

Berdasarkan tipe koleksem organisasi ini, dan juga koleksem nama dan namanya (2), verba membesarkan secara dominan (dalam korpus dan data yang dikaji) 
menyampaikan makna metaforis 'membuat sesuatu memiliki posisi penting'. Makna ini dilandasi dengan metafora konseptual PENTING ADALAH BESAR (Lakoff \& Johnson, 1980, hlm. 50). Metafora ini juga dicerminkan oleh ungkapan seperti nama/partai besar, hari raya, hari besar keagamaan.

(2) Sementara itu, terkait band Garasi yang telah membesarkan namanya, ia mengatakan [....] (ind_news_2011_300K:241163)

Makna metaforis lain yang diungkap berdasarkan koleksem pada Tabel 4 berkaitan dengan emosi (membesarkan hati) dan merawat anak (membesarkan anak [anak[nya]]). Distribusi koleksem serta ciri semantis berbeda dimiliki oleh memperbesar, seperti ditunjukkan pada Tabel 5.

\section{Tabel 5 Koleksem R1 khas signifikan untuk memperbesar dibandingkan dengan membesarkan}

\begin{tabular}{llllr} 
& W & memperbesar & membesarkan & collstr \\
\hline 1 & keunggulan & $107(61.71)$ & $0(45.29)$ & 28.47 \\
2 & kemenangan & $46(26.53)$ & $0(19.47)$ & 11.48 \\
3 & gol & $23(13.27)$ & $0(9.73)$ & 5.61 \\
4 & peluang & $18(10.38)$ & $0(7.62)$ & 4.37 \\
5 & pasar & $8(4.61)$ & $0(3.39)$ & 1.92 \\
6 & jumlah & $9(5.77)$ & $1(4.23)$ & 1.48
\end{tabular}

Salah satu temuan yang menarik dari Tabel 5 ialah hampir sebagian besar koleksem R1 khas signifikan untuk memperbesar juga tidak pernah muncul dengan membesarkan, kecuali jumlah, yang hanya muncul satu kali. Hal ini kembali menunjukkan ketimpangan distribusi di antara kedua verba tersebut seperti pada Tabel 4 sebelumnya.

Temuan menarik selanjutnya adalah tipe semantis dari koleksem khas memperbesar mencerminkan motivasi metafora konseptual yang berbeda terkait makna yang diungkap oleh memperbesar dibandingkan dengan membesarkan. Penulis berpendapat bahwa koleksem khas memperbesar tersebut mengisyaratkan makna 'peningkatan kuantitas' dari entitas yang diacu oleh koleksemnya. Makna ini tampak dilandasi oleh metafora konseptual KUANTITAS ADALAH UKURAN, khususnya LEBIH (BANYAK) ADALAH BESAR, yang juga tercermin dalam ungkapan makan besar, diskon besar-besaran (periksa Winter \& Matlock, 2013 untuk kajian eksperimental terhadap metafora LEBIH (BANYAK) ADALAH BESAR). Sebaliknya, konsep 'penting' atau 'signifikansi' yang diacu oleh membesarkan sebelumnya dapat dikatakan terpusat pada unsur 'kualitas' (mis. ketenaran) yang dimiliki oleh objek langsungnya (mis. suatu partai atau seseorang).

\section{PENUTUP}

Makalah ini berangkat dari salah satu klaim yang diajukan oleh Sneddon et al. (2010, hlm. 103) bahwa kebanyakan penutur BI tidak begitu memperhatikan perbedaan semantis antara dua verba kausatif deajektiva berdasarkan konstruksi morfologis perdan -kan $(\S 1)$. Dengan merumuskan asumsi tersebut berdasarkan pendekatan linguistik korpus dan semantik distribusional, makalah ini memperkenalkan Analisis Koleksem Khas (Distinctive Collexeme Analysis [DCA]) (\$2.2) sebagai salah satu metode kuantitatif untuk menguji asumsi tersebut berdasarkan data koleksem dari verba 
membesarkan dan memperbesar; koleksem yang difokuskan ialah satu kata yang mengikuti (atau di sebelah kanan) verba tersebut dalam korpus (koleksem R1) (§2.1).

Luaran DCA menunjukkan perbedaan substansial di antara membesarkan dan memperbesar, baik dari segi distribusi maupaun tipe semantis koleksem khasnya yang berkontribusi terhadap perbedaan semantis kedua verba tersebut ( $\$ 3)$. Secara khusus, penulis berpendapat bahwa koleksem R1 khas untuk membesarkan dan memperbesar mencerminkan dua motivasi metafora konseptual berbeda yang mencirikan makna dominan masing-masing verba tersebut: (i) PENTING ADALAH BESAR untuk membesarkan dan (ii) KUANTITAS ADALAH UKURAN dan LEBIH (BANYAK) ADALAH BESAR untuk memperbesar. Hasil DCA untuk kedua verba ini menunjukkan bahwa klaim terkait kemiripan semantis antara pasangan verba kausatif berakar sama dengan konstruksi $[$ per- $+\mathrm{AJ}]$ dan $[\mathrm{AJ}+-k a n]$ belum bisa dipertahankan, setidaknya berdasarkan data korpus dan untuk verba dengan akar kata besar. Di sisi lain, temuan ini mendukung asumsi bahwa terdapat pasangan verba deajektiva dengan per- dan -kan yang tidak dapat saling menggantikan secara semantis (Sneddon et al., 2010, hlm. 103).

Namun, sedikitnya terdapat dua hal yang mesti diperhatikan dari temuan ini. Pertama, hasil analisis makalah ini sangat terbatas pada (i) kata berakar besar, (ii) bentuk verba dalam diatesis aktif, (iii) rentang koleksem yang dikaji, serta (iv) ukuran dan jenis teks dalam korpus yang menjadi sumber data. Kedua, asumsi yang belum dapat dibuktikan melalui temuan korpus ini ialah representasi kognitif sejumlah pasangan verba deajektiva dengan per- dan -kan dalam minda penutur, yang bisa diuji melalui eksperimen psikolinguistik: apakah pengetahuan koleksem khas, khususnya untuk memperbesar dan membesarkan (beserta pasangan verba lainnya), juga menjadi bagian dari khasanah kebahasaan penutur BI? (periksa Gries, Hampe, \& Schönefeld, 2005 sebagai contoh kajian awal yang memadukan temuan Analisis Kolostruksional dengan hasil eksperimen) Kajian linguistik korpus kuantitatif menggunakan DCA (i) sedikitnya membantu menemukenali perbedaan dan batasan semantis di antara dua bentuk linguistik, yang dianggap memiliki kemiripan makna, dan (ii) menghasilkan suatu hipotesis berdasarkan data pemakaian (usage-based data) yang dapat diujikan dengan metode berbeda (mis. eksperimen psikolinguistik).

\section{DAFTAR PUSTAKA}

Biemann, C., Heyer, G., Quasthoff, U., \& Richter, M. (2007). The Leipzig Corpora Collection: Monolingual corpora of standard size. In M. Davies, P. Rayson, S. Hunston, \& P. Danielsson (Eds.), Proceedings of the Corpus Linguistics Conference. University of Birmingham, UK. Retrieved from http://ucrel.lancs.ac.uk/publications/CL2007/paper/190_Paper.pdf

Gries, S. T. (2013). Corpus linguistics: Quantitative methods. In C. A. Chapelle (Ed.), The Encyclopedia of Applied Linguistics (Vols. 1-10). Chichester, West Sussex, UK: Blackwell Publishing Ltd. doi:10.1002/9781405198431.wbeal0258

Gries, S. T., \& Stefanowitsch, A. (2004). Extending collostructional analysis: A corpusbased perspective on 'alternations'. International Journal of Corpus Linguistics, 9(1), 97-129.

Gries, S. T., Hampe, B., \& Schönefeld, D. (2005). Converging evidence: Bringing together experimental and corpus data on the association of verbs and constructions. Cognitive Linguistics, 16(4), 635-676. 
Janda, L. A. (2017). The quantitative turn. In B. Dancygier (Ed.), The Cambridge handbook of Cognitive Linguistics (pp. 498-514). New York, NY: Cambridge University Press. doi:10.1017/9781316339732.032

Lakoff, G., \& Johnson, M. (1980). Metaphors we live by. Chicago: The University of Chicago Press.

Lenci, A. (2008). Distributional semantics in linguistic and cognitive research. Italian Journal of Linguistics, 20(1), 1-31. Retrieved from http://linguistica.sns.it/RdL/20.1/ALenci.pdf

R Core Team. (2018). R: A language and environment for statistical computing. Vienna, Austria: R Foundation for Statistical Computing. Retrieved from https://www.R-project.org/

Rajeg, G. P. W. (2014). Metaphorical profiles of five Indonesian quasi-synonyms of ANGER: Multiple distinctive collexeme analysis. In Proceedings of the International Congress of the Linguistic Society of Indonesia 2014 (pp. 165 170). Bandar Lampung, Sumatra, Indonesia: Masyarakat Linguistik Indonesia (MLI). doi:10.4225/03/58578ddba1fd2

Rajeg, G. P. W. (2016, July). Collostructional analysis meets metaphors: A study on Indonesian near-synonyms of HAPPINESS. Presented at the Twentieth International Symposium on Malay/Indonesian Linguistics (ISMIL 20), The University of Melbourne, Australia. doi:10.4225/03/592e2ba2e6ea 7

Rajeg, G. P. W. (2018a). Collogetr: Collocates retriever and Collocation association measure (Version 1.0.2). doi:10.26180/5b7b9c5e32779

Rajeg, G. P. W. (2018b). Happyr: The accompanying R package for Rajeg's (2018) PhD thesis titled "Metaphorical profiles and near-synonyms: A corpus-based study of Indonesian words for Happiness" (Version 0.1.0). doi:10.5281/zenodo.1436331

Rajeg, G. P. W., \& Rajeg, I. M. (2017). Mempertemukan morfologi dan linguistik korpus: Kajian konstruksi pembentukan kata kerja [per-+Ajektiva] dalam Bahasa Indonesia. In I. N. Sudipa \& M. S. Satyawati (eds.), Rona Bahasa: Buku persembahan kepada Prof. Dr. Aron Meko Mbete memasuki masa purnatugas (pp. 288-327). Denpasar, Bali, Indonesia: Swasta Nulus. doi:10.4225/03/5a0627de02453

Rajeg, G. P. W., Denistia, K., \& Rajeg, I. M. (2018). Working with a linguistic corpus using R: An introductory note with Indonesian negating construction. Linguistik Indonesia, 36(1), 1-36. doi:10.4225/03/5a7ee2ac84303

Sneddon, J. N., Adelaar, A., Djenar, D. N., \& Ewing, M. C. (2010). Indonesian reference grammar (2nd ed.). Crows Nest, New South Wales, Australia: Allen \& Unwin.

Stefanowitsch, A. (2013). Collostructional analysis. In T. Hoffmann \& G. Trousdale (Eds.), The Oxford handbook of Construction Grammar (pp. 290-306). Oxford: Oxford University Press. doi:10.1093/oxfordhb/9780195396683.013.0016

Stefanowitsch, A. (2014). Collostructional analysis: A case study of the English intocausative. In T. Herbst, H.-J. Schmid, \& S. Faulhaber (Eds.), Constructions collocations patterns (pp. 217-238). Berlin ; Boston: Walter De Gruyter, GmbH.

Stefanowitsch, A., \& Gries, S. T. (2003). Collostructions: Investigating the interaction of words and constructions. International Journal of Corpus Linguistics, 8(2), 209-243.

Winter, B., \& Matlock, T. (2013). Creativity and the sensorimotor grounding of mathematics. In M. Borkent, B. Dancygier, \& J. Hinnell (Eds.), Language and 
the creative mind (pp. 37-48). Stanford, California: CSLI Publications.

Retrieved from http://www.bodowinter.com/papers/bwtm_creativity_math.pdf 